\title{
JURISPRUDENTIAL PERSPECTIVES ON THE FOUNTAIN OF NIGERIA LEGAL SYSTEM
}

\author{
L-A. AYINLA
}

\section{Lukman Alabi AYINLA}

Faculty of Law University of Ilorin, Ilorin, Nigeria

Ph.D, (IIUM, Malaysia), LL.M (OAU, Ile-Ife, Nigeria), BL. (Abuja, Nigeria), LL.B. (Combined Hons., UDUS, Nigeria), Associate Professor (Reader) Faculty of Law, University of Ilorin, Ilorin, Nigeria.

E-mail: lukmanayinla@gmail.com

\section{ABSTRACT}

The basis of the Nigerian legal system appears multi-faceted, the fact that the country had contact with colonialism and the intervening military rule as against a truly democratic arrangement bequeathed at the independence of the country are source of concern. The paper adopts the doctrinal research method to attempt a critique of perspectives of the actual basis of the Nigeria legal system. The paper looks at some relevant concepts, the fountain in term of the grundnorm, customary law together with brief historical facts, and characteristic nature of Nigeria legal system to interrogate some perspectives. The paper founds that the fountain of the legal system is more of being jurisprudential in nature and concludes that the basis of Nigerian legal system is multi-faceted but ultimately founded on the constitution.

KEYWORDS: Law, Jurisprudence, Custom, Nigeria Legal System

\section{INTRODUCTION}

The basis of the Nigerian legal system cannot be divorced from the idea of a legal system. Foundation is the basis of which something is supported, founded on - having as a basis. ${ }^{1}$ Besides, legal connotes, of or relating to law, falling within the province of law. ${ }^{2} \mathrm{~A}$ system on the other hand, is described as considered principles or procedures of classification. A legal system encapsulates the principles or procedures for the classification of laws, procedures, including the principles and rules that have the force of law in a given society. ${ }^{3}$ Thus, the Nigeria legal system is an embodiment of the laws, courts, legal personal and the totality of the administration of justice generally. The foundation or the fountain of something may be argued to presuppose the basis, the fountain, or spring from which anything rises from. However, it is argued by Asien ${ }^{4}$ that the idea of a legal system comprises of a legal order of normative rules. Okonkwo posited that the Nigeria legal system comprises of the totality of the laws or legal rules and the legal machinery which obtain within Nigeria as a sovereign and independent African country. ${ }^{5}$ One may therefore conclude that the foundation of Nigeria legal system is the basis / fountain of the laws, principles, procedures, courts and the basis of the totality of the Nigerian administration of justice as known and validated under the prior and present legal order in Nigeria.

\section{PERSPECTIVES ON THE FOUNDATION AND CRITIQUE OF THE GRUNDNORM}

\footnotetext{
${ }^{1}$ A. Bryan, Garner, ed., Black's Law Dictionary, $9^{\text {th }}$ edn., West Publishing Company, US, 1990, p. 727

${ }^{2}$ Ibid, p. 975

${ }^{3}$ P. D. Mission, Nigerian Legal System, www.nigerianlawclaz.blogspot.com accessed $11^{\text {th }}$ April, 2019

${ }^{4}$ O. J. Asien, Introduction to Nigerian Legal System, $2^{\text {nd }}$ edn., Ababa Press, Lagos, 2005, p. 1

${ }^{5}$ C. O. Okonkwo, ed., Introduction to Nigerian Law, Sweet \& Maxwell, London, 1980, p. 40
} 


\section{Lukman Alabi Ayinla}

Sovereignty and the idea of a state are two important concepts that are inseparable. A state presupposes an association of men and women with a definite territory and an organized system / structure of government. ${ }^{6}$ The organized system of government presupposes inclusion of the legal system. Thus the idea of a foundation of all the rules in a legitimate, valid or organized legal system has been argued in the light of the grundnorm, which has been described by some scholars as the ultimate rule or basic norm, due to its essence as it establishes and legalizes the structure and workings of the institutions and legal principles within the legal structure because it is seen as the ultimate legal authority and the highest norm. ${ }^{7}$ Although further deductions can be distilled from the analysis of Hans Kelsen when he offered the Pure Theory of Law, he argued that by basic norm he meant the higher law in a legal system. That law is valid in so far as it is created by a higher norm, the norm should be traceable to a non-law created entity known as the grundnorm. He concluded by holding that grundnorm is the ultimate norm in the multiplicity of norms. Although scholars are not unanimous on the argument surrounding grundnorm but Orji ${ }^{8}$ held the view that constitution of the Federal Republic of Nigeria is the grundnorm because any act or law contrary to it will be declared null and void and of no effect whatsoever. ${ }^{9}$ The constitution is supreme with an overriding authority over all other law to the extent that any inconsistency with the constitution renders the law null and void and of no effect whatsoever.

\subsection{Perspective on the Fountainhead / the Foundation}

The idea of a fountain or foundation of the Nigeria legal system is more jurisprudential in nature than a mere critique of the foundation of the legal system simpliciter. This is so, in that, the foundation may be stretched so far to encapsulate the premise or basis of the Nigeria legal system to ascertain the fons et origo (source) of the legal system. However, before delving into the main discourse it is apposite to loosely conclude that the basis or the fountainhead of the legal system cannot be too far from the major spring or fountain of the primary sources of law as in the constitution, statutes and cases. ${ }^{10}$

However, the Nigeria legal history may not validly and necessarily support this form of sweeping conclusion but to inferably necessitate a peep exposition into the legal history of the country. Nigeria as a country was formerly a British colony, and presently it has a population of over 180 million people, over 250 ethnic groups with different religious belief. ${ }^{11}$ The country has a history of a rich cultural background that is still very much embedded in the country's daily life. Thus, to appraise the basis of Nigeria legal system, it is a fact that custom / customary law played a significant role in the pre-colonial life of Nigeria.

\section{PERSPECTIVE ON CUSTOM / CUSTOMARY LAW}

It is pertinent to state that there had been established legal system in Nigeria before the British's introduction of the English law into Nigeria, although the system is one that seeks to promote communal welfare and social well-being by maintaining social equilibrium. ${ }^{12}$ Customs are the general rules of behavior that develop in a community without being

\footnotetext{
${ }^{6}$ See Section 318 of the Constitution of the Federal Republic of Nigeria 1999

${ }^{7}$ O. J. Asien., Op. Cit. p. 1. See also, O. Abiola, Constitutional Law and Military Rule in Nigeria, Evans Publication, Ibadan, 1987, pp.82-84, K. Eso, Is There a Nigerian Grundnorm?, Lecture delivered at the First Justice Idigbe Memorial Lecture, University of Benin, $31^{\text {st }}$ January, 1985, p.5

${ }^{8}$ S. I. Oji, Introduction to Legal Method, Ababa Press, Nigeria, 2011, pp. 9-10

9 Section 1, Constitution of the Federal Republic of Nigeria1999, see also Olakanmi \& Co., The Nigerian Constitutions 1963, 1979 \& 1999, a Compendium, $3{ }^{\text {rd }}$ edn., LawLords Publications, Abuja, 2008, p.iii

${ }^{10}$ S. I. Oji, Op. Cit., p.144

${ }^{11}$ A.A. Oba, Religious and Customary Law in Nigeria, Emory International Law Review, Vol. 25, p.882, 2011.

${ }^{12}$ T. Niki, Sources of Nigerian Law, MIJ Publishers, Lagos, 1996, p. 1, see also L.A. Ayinla, The Nigerian Living Law and Its Relegation, the Sociological and Historical Perspectives, University of Ilorin Law Journal, Vol.1, p. 2012006
} 


\section{JURISPRUDENTIAL PERSPECTIVES ON THE FOUNTAIN OF NIGERIA LEGAL SYSTEM}

invented deliberately. In fact, historically they are effectively the basis of the common law. ${ }^{13}$ The truth is that custom is known to many jurisdictions of the world although in different forms, Martin stated that:

- the law of England and Wales has been built up very gradually over the centuries. There is not just one way of creating or developing law; there have been, and still are, a number of different ways. These methods of developing laws are usually referred to as sources of law. Historically, the most important ways are customs and decisions of judges. Then, as parliament became more powerful in the eighteenth and early 19th centuries, Acts of Parliament were the main source of new laws, although judicial decisions were still important as they interpreted the Parliament law and fill in gaps where there was no statute law ${ }^{14}$

The position is the same with Nigeria and it will be safe to conclude that the law common to the whole of Africa and Nigeria in particular is the customary law. This is the law known to the natives, in that this is the common law of Nigeria as found in the various localities within the various ethnic groups in Nigeria as it regulates ${ }^{15}$ the lives of the inhabitants (Africans / Nigerians) particularly in the area of personal law ${ }^{16}$ and by necessary implication, customary law was the law known to the natives ever before the introduction of English law and the attendant validity tests by the colonial masters. ${ }^{17}$ It is a fact that in the various communities there were organized structures of government, although in various forms and degrees of perfection in tune with the level of development of the communities. ${ }^{18}$ It should be stated that when the colony of Lagos was created in $1862^{19}$ and by virtue of order No.3 of 1863, English law was also introduced. The customary law on ground was allowed to operate side by side with the introduced laws but was later relegated due to its unwritten nature and the advent colonialism that brought about new situations and new persons to whom customary law was grossly inadequate. However, it may be asserted that customary law is not uniform but the uniformity is only peculiar to the individual community, thus cannot be universal due to the multi-cultural ethnic groups that existed in the different parts of Nigeria. ${ }^{20}$ The introduction and acceptance of English law was not because English law was the greatest juridical system or a reflection of the traditional and cultural legal system of the local populace but by sheer dictate of history and irresistible imposition on the country vide colonization. ${ }^{21}$ The fact is that, although the colonial masters viewed English law as the foundation and cynosure of justice ${ }^{22}$, whereas, in Africa, law is seen as an integral part of the totality of the African culture. It is so much embedded that it is perceived as an instrument of maintaining social equilibrium with emphasis on distributive justice rather than formal justice as emphasized under the western jurisprudence. Thus African philosophy of law entails the pursuit of wisdom or of knowledge of law as obtainable in African societies, including the study of the law. ${ }^{23}$ It is worthy of note to state that the pronouncement of the Supreme court of Nigeria in Joseph Ohai v. Samuel Akpoemonye ${ }^{24}$ is commendable in showing the peculiarity of the law where it held that customary law is:

\footnotetext{
${ }^{13}$ M. Jacqueline, The English Legal System, $7^{\text {th }}$ Edn., Hodder Education, Italy, 2013, p.15 ${ }^{14}$ Ibid

${ }^{15}$ A.E.W. Park, The Sources of Nigerian Law, African University Press, Lagos, 1963, p.1

${ }^{16}$ A. Emiola, The Principles of African Customary Law, Emiola Publishers, Nigeria, 2005, pp. 5-75

${ }^{17}$ A.E.W. Park, Op. Cit., p.11

${ }^{18}$ Emiola A., Op. Cit., p.1

${ }^{19}$ O. J. Asien, Introduction to Nigerian Legal System, Sam Bookman Publisher, Ibadan, 1997, pp. 109-110

${ }^{20}$ W. Kamau, Customary Law and Women's Right in Kenya, www.theequitysffect.org $>$ uploads $>2014 / 12$ accessed 14th March, 2019.

${ }^{21}$ L. A. Ayinla, The Nigerian Living Law and Its Relegation, the Sociological and Historical Perspectives, University of Ilorin Law Journal, Vol.1, pp. 202-203, 2006.

${ }^{22}$ H. F. Morris, J.S., Indirect Rule and the Search for Justice, 1972, pp.72-83, cited in T. Niki, Op. Cit, pp.17-18

${ }^{23}$ L. A. Ayinla, African Philosophy of Law: A Critique, Journal of International and Comparative Law, Vol.6, p. 147,2002 ,

${ }^{24}$ (1999) 1SCNJ 73
} 
- any system of law not being the common law and not being a law enacted by any competent legislature in Nigeria but which is enforceable and binding within Nigeria as between the parties subject of its sway.

\section{PERSPECTIVE ON BRIEF HISTORICAL FACTS, FACTORS NECESSITATING ENGLISH LAW AND THE CONSTITUTION}

A number of scholars ${ }^{25}$ have identified the factors that were responsible for the introduction / reception of English law as earlier stated. Other factors include the arrival of Europeans in fairly large numbers together with large scale commercial activities. The acquisition of power by Britain and the attendant introduction of new practices and new institutions as well as the unwillingness to be bound by tribal / native laws and custom contrary to the background and society in which they were nurtured.

As rightly observed, there was a system of administration of justice in Nigeria prior to colonization in Nigeria. Before 1862 in the now Northern State of Nigeria, the Islamic law of the Maliki School of Thought was applied ${ }^{26}$ as it is still in practice up till the present day. In the Southern parts the unwritten customary law was applied, although customary courts in place appears strange to the British merchants / foreign traders which was contrary to the common law of England that they were already well acquainted with. Thus the bulk of English law- the common law, equity and English statutes were received.

Sequel to the formation of the Southern protectorate on $1^{\text {st }}$ January 1900 and Northern Protectorate, and the later amalgamation of the Colony and Protectorate of Lagos and the Protectorate of Southern Nigeria to form the Colony and Protectorate of Southern Nigeria in 1906. The year 1914 was spectacular in that it ushered in the amalgamation of the Colony and Protectorate of Southern Nigeria and the Protectorate of Northern Nigeria to form the Colony and Protectorate of Nigeria therefore marking the coming into existence of Nigeria. A cursory perusal of the following order reveals the formal coming into being of Nigeria:

By order (Nigeria Protectorate Order in Council 1913) of His Majesty George the $5^{\text {th }}$, made on the $22^{\text {nd }}$ November, 1913 , by virtue and in the exercise of the powers vested in his majesty by the Foreign Jurisdiction Act, 1890, the country known as Nigeria was legally born with effect from the $1^{\text {st }}$ of January, 1914 because, the order was made to come into operation on the $1^{\text {st }}$ day of January, $1914 .^{27}$

Sequel to the official birth of Nigeria as a political unit having been unified, ever since then the country has consistently lived with the reality of the various courts in form of the Supreme Court, Provincial Court and Native Courts. Although in view of the criticisms of the system, the establishment of a High Court and Magistrate Court were effected in 1933 vide the protectorate court ordinance No. 45 of $1933 .{ }^{28}$ However, the 1954 Federal Constitution brought about the introduction of three Regions, a Federal Territory in Lagos, a Federal Supreme Court, a High Court for each region and Magistrate Courts. Customary Courts were established for the Western and Eastern region and Native court for the Northern region. On the $1^{\text {st }}$ of October, 1960 Nigeria gained independence and by 1963 another constitution came into being by virtue of which the country became a Republic and the constitution abolished monarchy and ceased to be under the Queen. Besides, a new Supreme Court of Nigeria was established as the highest court in Nigeria. ${ }^{29}$

It should be stated that the wheel of progress of the country was clogged by the military vide coup deta't on $15^{\text {th }}$ January, 1966. This was justified by the military junta on the

\footnotetext{
${ }^{25}$ T. Niki, A.E.W. Park, Op. Cit. pp.16-17

${ }^{26}$ A.O. Obilade, The Nigerian Legal System, Spectrum Books Ltd, Ibadan 1979, reprinted 2011, p.17

${ }^{27}$ See G. Fawehinmi, Courts'System in Nigeria - A Guide (1922), Nigerian Law Publications Ltd., Lagos, 1992, p. 2

${ }_{28}^{28}$ A. O. Obilade, Op. Cit., pp. 32-33

${ }^{29}$ Ibid
} 


\section{JURISPRUDENTIAL PERSPECTIVES ON THE FOUNTAIN OF NIGERIA LEGAL SYSTEM}

unhealthy political crises and the need for an intervention to stabilize the polity. This military revolution led to the suspension of the constitution vide the Constitution Suspension and Modification Decree 1966. This is how Military intervention found its way into the administration of government in Nigeria. The 1979 constitution was midwife by General Olusegun Obasanjo. There was also a military take over from the military government of Gen. Muhammadu Buhari that ushered in the military regime of General Ibrahim Babangida who later step aside. The important aspect here is that the emergence of Gen. Abdulsalami Abubakar enhanced a revisit to the 1979 constitution for possible review, modification and amendment to return Nigeria back into a democratic government, this objective was achieved and produced the 1999 constitution. ${ }^{30}$ It must be stated here that notwithstanding the operation of a democratic government in Nigeria under a constitution, a lot of arguments have ensued generally on the validity of the constitution, on the premised that the constitution under which the present dispensation is being administered is not democratic but a decree so named a constitution. Thus necessitating the call for a revisit of the current constitution by convening a properly constituted constitutional conference to bring about a democratic constitution in Nigeria. A comparism of the two provisions of the following constitutional provision may better illustrate the argument:

Having firmly resolved to establish the Federal Republic of Nigeria, with a view to ensuring the unity of our people and faith in our fatherland. For the purpose of promoting inter-African co-operation and solidarity,

In order to assure world peace and international understanding, and so as to further the ends of liberty, equality and justice both in our country and in the world at large,

We the people of Nigeria, by our representatives here in Parliament assembled, do hereby declare, enact and give to ourselves the following Constitution; $-{ }^{31}$

The above provision clearly shows that it is the people of Nigeria through their representative in parliament duly constituted that produced a constitution that reflects that yawning and aspirations of the people of Nigeria, unlike this other provision which is a decree, as embedded in the 1999 constitution. The constitution is therefore made a schedule to the said decree as promulgated by the military:

NOW THEREFORE, THE FEDERAL MILITARY GOVERNMENT hereby decrees as follows:-

1.(1) There shall be for Nigeria a Constitution which shall be as set out in the schedule to this Decree.

(2) The Constitution set out in the schedule to this Decree shall come into force on $29^{\text {th }}$ May 1999.

(3) Whenever it may hereafter be necessary for the constitution to be printed it shall be lawful for the Federal Government Printer to omit all parts of this Decree apart from the schedule and the Constitution as so printed shall have the force of law notwithstanding the omission. ${ }^{32}$

It is apposite to say caveat emptor, although this is not a contractual obligation or discussion on tort but it is valid to say res ipsa loquitor- that the thing has spoken for itself. It is logical to ensure that a constitution that reflects the values, yawning and aspiration of the people of Nigeria should be enacted to capture the various alterations to the constitution which is also an effort to produce a good democratic compliant and democratically enabled and informed constitution.

\footnotetext{
${ }^{30}$ Olakanmi \& Co., Op. Cit., pp. i-ii

${ }^{31}$ Constitution of the Federal Republic of Nigeria 1963, No. 20 (AN ACT TO MAKE PROVISION CONSTITUTION OF THE FEDERAL REPUBLIC OF NIGERIA)

${ }^{32}$ Constitution of the Federal Republic of Nigeria 1999, Decree No. 24, CONSTITUTION OF THE FEDERAL REPUBLIC OF NIGERIA (PROMULGATION) DECREE 1999
} 


\section{CHARACTERISTIC NATURE OF NIGERIAN LEGAL SYSTEM, COMPLEXITY, MULTIPLICITY AND UNIFICATION}

As already identified, in the present day Nigeria and particularly based on the historical / legal antecedent of the country, the Federal Republic of Nigeriais basically a constitutional republic and by necessary implication the Nigeria legal system is based on the English common law and legal tradition due to the legal transplant occasioned by colonization and the eventual reception of English law into Nigeria. The above notwithstanding, which is a reality that continue to dwell with us because English law forms the basis and the yard stick with which the standard of the Nigerian legal system is measured, this has not in any way change and remove completely the reality of the character and complexity of the Nigerian legal system.

It must be borne in mind that the determination of the applicable laws at times reveals the difficulty in choosing an applicable law in situations where there is the likelihood / possibility of the application of a variety of applicable laws. Actually, this is a situation where the knowledge of the application of conflict of laws becomes relevant. However, in view of the multiplicity of legal system, the determination of an applicable law may require the ascertainment of the personal law of the party. In Nigeria for example, there are different personal law determinable by reference to - under common law, domicile is employed, under civil law reference is made to nationality, while under Islamic law, reference is made to religion. The preceding are the important connecting factors that are employed in the determination of personal law generally, but in Nigeria, domicile is usually employed to determine the personal of law of a propositus. ${ }^{33}$ In the case of Omotunde v Omotunde, the perfect idea of domicile under the Nigeria private international law was captured in the following words:

Everybody at birth becomes a member of both a political and of a civil society, the former determines his political status and nationality, and the latter determines his civil status. The law which governs the civil society into which he is born is the law of his country of domicile.

The problem of determination of applicable law is as a result of the problem usually posed by the challenges of internal conflict of laws occasionally. The multiplicity nature of the Nigerian legal system is so unique that the courts have validated recognition of the various laws. In Re Sarah Adadevoh v In the Estate of Macaulay, ${ }^{34}$ the court held that:

Legitimate is to be determined by the native law and custom applicable to the deceased and not the English Law

This further informed the pronouncement of the Supreme Court of Nigeria in Adeyemi $\mathrm{v}$ Bamidele, ${ }^{35}$ in distinguishing between legitimacy in England and the concept of legitimacy in Nigeria as two different concepts. The same position had earlier been taken by the court ${ }^{36}$ to the effect that legitimate children in Nigeria are not confined or limited to children born in wedlock or children legitimated by subsequent marriage of the parents as in England but extends to issue born without marriage and can be a legitimate child in so far as the paternity of the child is acknowledged by the putative father.

The courts have well validated the recognition of the pluralistic nature of our legal system by recognizing English law, Customary Law and Islamic Law. The practicability of this may be seen in the cases of Ajibaiye v. Ajibaiye, Olowu v Olowu ${ }^{37}$, IlaAlkamawa v

\footnotetext{
${ }^{33}$ L.A. Ayinla, G.H. Olusola, Domicile and The Determination of Personal: A Critique, EBSU Journal of International Law and Juridical Review, Vol.3, pp. 9-11, 2014.Ssee also R.H. Graveson, Conflict of Laws, $6^{\text {th }}$ edn., Sweet \& Maxwell, London, 1969, p.20

${ }^{34}(1950-51) 13$ WACA 304

${ }^{35}$ (1968) 1 ALL NLR 31 at 37

${ }^{36}$ Lawal v Younan (1961) 1 ALL NLR 145

${ }^{37}$ (1985) 3 NWLR (pt. 13) 372
} 


\section{SYSTEM}

Hassan Bello. ${ }^{38}$ Thus the necessary implication of the foregoing is that other laws are being recognized as forming part and parcel of the Nigerian legal system.

It is must be noted that with the reception formula, there appear a history of reception that favours the application of law to suit local circumstance, a look at the Interpretation Act reveals this analysis. Section 45(1) of the interpretation Act is as follows:

45(1) Subject to the provisions of this section, and except in so far as other provision is made by any Federal law, the common law of England and the doctrine of equity, together with the statute of general application that were in force in England on the $1^{\text {st }}$ day of January 1900, shall be in force in Lagos and, in so far as they relate to any matter within the exclusive legislative competence of the Federal legislature, shall be in force elsewhere in the federation.

(2) Such imperial laws shall be in force so far only as the limit of the local jurisdiction and local circumstances shall permit and subject to any Federal law.

(3) For the purpose of facilitating the application of the said imperial laws they shall be read with such formal verbal alterations not affecting the substance as to names, localities, courts, officers, persons, moneys, penalties and otherwise as may be necessary to render the same applicable to the circumstances.

The above provision is argued to leave room for some possibilities as in, received English law can be amended or repealed even by enactments of the Nigerian legislature, it may also provide reference to English law in the absence of a local legislation and it as well allowed for the continued operation of customary laws. ${ }^{39}$

However, notwithstanding the multiplicity nature of the legal system, the current situations / circumstances favours repealed / amendment of laws in line with current realities, the constitution having empowered the various legislature in this regard.

\section{APPRAISAL OF PERSPECTIVES}

As rightly observed that the Nigerian legal system cannot be divorced from the grip of colonialism totally, it continues to reflect the tradition / customary character of the country. Some writers have observed certain peculiarity of Nigerian legal system. Daniel ${ }^{40}$ argued generally that the feature of the Nigerian legal system may be seen in its duality, duality by comprising English law, Islamic law and Customary law. It is therefore the contention of this writer that this proposition can be better ascribed to as the pluralistic nature of the Nigerian legal system which has been validated both in law and practice as already discussed.

The idea of external influence is further argued as the importation of both Islamic law from the Middle East as a result of trans-border trade / commercial interactions which has permanently influenced the various customary practices / customary laws to favour the practice of Islamic law particularly in the generality of the Northern Nigeria with relatively few exceptions in some states like Kaduna, Jos among others where Christianity is well rooted in some areas. The reason may be adduced on the importation of English laws into Nigeria due to the arrival of the European traders and the subsequent and eventual colonization of Nigeria.

The other argument put up by Daniel is the identification of the Geo-Cultural diversity of the country. The heterogeneous nature of Nigeria with over 250 ethnic nationalities together with the unwritten nature of the custom, this is argued to have made it difficult to achieve uniformity of the various customs thus prompting different attempt at either codification / restatement of customary laws. Besides, the system of precedent is also a significant character of the Nigerian legal system. The idea of precedent entrenches the

\footnotetext{
${ }^{38}$ Alhaji Ila Alkamawa v Alhaji Hassan Bello \& 7 Ors. (1998) 6 SCN 126-136. See also A.A. Oba, Islamic Law as Customary Law: The Changing Perspective in Nigeria, International and Comparative Law Quarterly, Vol. 51, No. 4, pp.817- 850, 2002.

${ }^{39}$ A.E.W. Park, Op. Cit. pp.18-19

${ }^{40}$ P. D. Mission, Op. Cit. 2019
} 


\section{Lukman Alabi Ayinla}

doctrine of stare decisis, this is a latin word that is also peculiar to the English legal system, it is written in full as- stare decisis et non quietamovere and usually abridge as stare decisis meaning to stand by what has been decided and do not unsettle the established. ${ }^{41}$ It is to ensure fairness, guide against bias and ensure certainty in practice. It must be noted that judicial precedent refers to the source of law where past decisions of the judges create law for future judges to follow and abide, it is also known as case law. It is a major source of law both historically and up till the present day. ${ }^{42}$ Under the Nigerian legal system it is clear that the judicial powers of the State is vested in the courts. Section 6 (1) of the Constitution is explicit on this that:

The judicial power of the federation shall be vested in the courts to which this section relate being courts established for the federation." And as well, "The judicial power of the state shall be vested in the courts to which this section relate being courts established, subject as provided by this constitution, for a state ${ }^{43}$

The above sections are meaningful in furtherance of the entrenchment of the doctrine of stare decisis in Nigeria to ensure certainty and predictability of cases with similar fact. This has also strengthened the hierarchy of courts as enshrined in the constitution together with a good law reporting system.

Another issue identified is military influence that has in ways affected the legal system by imputing military flavour vide the various military take overs which had infected the system with various decrees and edicts as the case may be. This is believed to have distorted the democratic nature of the country in term of legal development, economic growth and development. This intervention is already shown to have fueled assertion of scholars to hold that the present Nigerian constitution is brought about vide a military decree and can only be better operated in that light, hence the need for a democratically processed constitution for Nigeria becomes imperative.

The above perspectives may summarily be understood from the pluralistic nature of the legal system that favours the recognition of Islamic Law and Customary Law, English law (particularly principles of common law). ${ }^{44}$ It is a fact that the multiplicity of law, particularly the disparity in the various system operated in the South and North as seen in the Criminal Code and the Penal Code, as well as the Criminal Procedure Code and the Criminal Procedure Act are also part of the nature of the system, although recent attempt is made to ensure unification in law and practice. One of such attempt is the Administration of Criminal Justice Act.

\section{CONCLUSION}

The totality of the above discussion is towards an attempt at critiquing the basis / fountain of the Nigerian legal system. However, in the contemporary day, the basis of the Nigerian legal system can validly be said to rest on the above arguments / discussions as embedded in the historical legal traditions of Nigeria as painstakingly analysed and espoused by scholars. Thus to be specific and direct, the Nigerian legal system is premised on the received English law that comprises of- the principles of common law, the doctrines of equity and statute of general application. It is as well based on Nigerian legislation as enacted by the federal and state legislatures- including the Acts, Laws, rules and regulation, as well as the various delegated legislations. Islamic law is also a valid law on which the legal system is founded in so far as it does not in any way contradicts the constitution and other laws in force. Case law in term of judicial precedent is also a major base upon which the Nigerian legal system is founded, in view of the doctrine of stare decisis. The Nigerian legal system is as

\footnotetext{
${ }^{41}$ M. Jacqueline, Op. Cit., p.23

${ }^{42}$ Ibid

${ }^{43}$ Section 6 (2) CFRN 1999

${ }^{44}$ See Section 1 (1), 1(3), 21, 315 CFRN 1999, see the cases of Saraki v FRN (2016) LPELR 40013 (SC) p. 109 \& NCP v National Assembly, FRN (2016) 1 NWLR (pt. 1492) 1 at 21.
} 


\section{JURISPRUDENTIAL PERSPECTIVES ON THE FOUNTAIN OF NIGERIA LEGAL \\ SYSTEM}

well based on international laws to which the country is signatory as validated in the celebrated case of Fawehinmi $v$ Abacha, the law must as well comply with the dictate of section 12 of the Nigeria constitution, in that the constitution determines the extent of the application of international instruments. However, much had been said on customary law, it is as well a major base of the Nigerian legal system provided it is in consonance with the law and having satisfied the validity tests.

Ultimately, the Nigerian legal system is based on the primary and secondary sources of law. It is important to reiterate that the Constitution of the Federal Republic of Nigeria is supreme and it is the fons et origo of all laws in Nigeria, it has an overriding authority over persons and authorities and by necessary implication the fountainhead of all laws and the basis of the Nigerian legal system.

\section{BIBLIOGRAPHY:}

A. Bryan, Garner, ed., Black's Law Dictionary, $9^{\text {th }}$ edn., West Publishing Company, US, 1990,

P. D. Mission, Nigerian Legal System, www.nigerianlawclaz.blogspot.com accessed $11^{\text {th }}$ April, 2019

O. J. Asien, Introduction to Nigerian Legal System, $2^{\text {nd }}$ edn., Ababa Press, Lagos, 2005,

C. O. Okonkwo, ed., Introduction to Nigerian Law, Sweet \& Maxwell, London, 1980,

See Section 318 of the Constitution of the Federal Republic of Nigeria 1999,

O. J. Asien., Op. Cit. p. 1. See also, O. Abiola, Constitutional Law and Military Rule in Nigeria, Evans Publication, Ibadan, 1987, pp.82-84, K. Eso, Is There a Nigerian Grundnorm?, Lecture delivered at the First Justice Idigbe Memorial Lecture, University of Benin, $31^{\text {st }}$ January, 1985,

S. I. Oji, Introduction to Legal Method, Ababa Press, Nigeria, 2011,

Section 1, Constitution of the Federal Republic of Nigeria1999, see also Olakanmi \& Co., The Nigerian Constitutions 1963, 1979 \& 1999, a Compendium, $3^{\text {rd }}$ edn., LawLords Publications, Abuja, 2008,

A.A. Oba, Religious and Customary Law in Nigeria, Emory International Law Review, Vol. $25,2011$.

T. Niki, Sources of Nigerian Law, MIJ Publishers, Lagos, 1996, p. 1, see also L.A. Ayinla, The Nigerian Living Law and Its Relegation, the Sociological and Historical Perspectives, University of Ilorin Law Journal, Vol.1, 2006

M. Jacqueline, The English Legal System, $7^{\text {th }}$ Edn., Hodder Education, Italy, 2013,

A.E.W. Park, The Sources of Nigerian Law, African University Press, Lagos, 1963,

A. Emiola, The Principles of African Customary Law, Emiola Publishers, Nigeria, 2005,

O. J. Asien, Introduction to Nigerian Legal System, Sam Bookman Publisher, Ibadan, 1997,

W. Kamau, Customary Law and Women's Right in Kenya, www.theequitysffect.org>uploads>2014/12 accessed 14th March, 2019.

L. A. Ayinla, The Nigerian Living Law and Its Relegation, the Sociological and Historical Perspectives, University of Ilorin Law Journal, Vol.1, 2006.

H. F. Morris, J.S., Indirect Rule and the Search for Justice, 1972,

L. A. Ayinla, African Philosophy of Law: A Critique, Journal of International and Comparative Law, Vol.6, 2002,

A.O. Obilade, The Nigerian Legal System, Spectrum Books Ltd, Ibadan 1979, reprinted 2011, See G. Fawehinmi, Courts' System in Nigeria - A Guide (1922), Nigerian Law Publications Ltd., Lagos, 1992,

Constitution of the Federal Republic of Nigeria 1963, No. 20 (AN ACT TO MAKE PROVISION CONSTITUTION OF THE FEDERAL REPUBLIC OF NIGERIA)

Constitution of the Federal Republic of Nigeria 1999, Decree No. 24, CONSTITUTION OF THE FEDERAL REPUBLIC OF NIGERIA (PROMULGATION) DECREE 1999 


\section{Lukman Alabi Ayinla}

L.A. Ayinla, G.H. Olusola, Domicile and The Determination of Personal: A Critique, EBSU Journal of International Law and Juridical Review, Vol.3, 2014.

See also R.H. Graveson, Conflict of Laws, $6^{\text {th }}$ edn., Sweet \& Maxwell, London, 1969,

Alhaji Ila Alkamawa v Alhaji Hassan Bello \& 7 Ors. (1998) 6 SCN 126-136. See also A.A. Oba, Islamic Law as Customary Law: The Changing Perspective in Nigeria, International and Comparative Law Quarterly, Vol. 51, No. 4, 2002. 